\title{
PEDAGOGISING POVERTY ALLEVIATION: a discourse analysis of education and social policies in Argentina and Chile ${ }^{1}$
}

Draft paper.

Final and reviewed version in: Rambla, X.; Verger, A. (2009) Pedagogising Poverty Alleviation: a discourse analysis of education and social policies in Argentina and Chile. British Journal of Sociology of Education. 30(4), 463- 477.

\section{XAVIER RAMBLA}

ANTONI VERGER

Corresponding Author:

Xavier Rambla

Seminar for the Analysis of Social Policy (SAPS: http://sapsuab.wordpress.com/)

Interdisciplinary Group on Education Policy (GIPE: http://www.ub.edu/gipe/)

Department of Sociology (Universitat Autònoma de Barcelona)

Edifici B. Campus de Bellatera. 08193- Cerdanyola (Barcelona: Spain)

Tf: 0034-93-581.40.93

Fax: 00-34-93-581 2827

e-mail: xavier.rambla@uab.cat

Biographical details

Xavier Rambla is Associate Professor at the Department of Sociology, Universitat Autònoma de Barcelona (UAB). He has also held academic positions in other institutions as a lecturer (Universitat de Vic, 1995-2001) as well as a researcher (Critical Co-education Programme, Institute of Education, UAB, 1994-2000). His main sociological interests include education, globalisation and inequalities. He co-ordinates a comparative research programme on education policy and development in Southern America (funded by the Ministry of Science, Spain).

Antoni Verger is Post- Doctoral Researcher at the Amsterdam Institute for Metropolitan and International Development Studies (AMIDSt), Universiteit van Amsterdam (UvA). He holds a degree on education (Universitat de les Illes Balears), and finished his $\mathrm{PhD}$ project at the Sociology Doctoral Programme (UAB, 2007). His main research interests are education and development, and social movements. Currently, he is conducting research on the global educational agenda and the implementation of this policy in Southern America.

\footnotetext{
${ }^{1}$ This piece of research is an outcome of the following project: "Beyond 'targeting the poor': education, development and poverty alleviation in the Southern Cone. An analysis of the new political agenda in the region" It has been funded by the Ministry of Education and Science (Government of Spain: reference SEJ2005-04235). We acknowledge the insightful suggestions of Carla Frías (research student with a Republic of Chile Scholarship), drawing on her fieldwork carried out in 2006.
} 


\section{ABSTRACT}

For the last decades international organisations and governments have promoted and implemented analogous education policies on the grounds that education is the key factor to foster development and fight poverty. This article sets the context of these educational programmes and analyses their discourse on poverty in Argentina and Chile. Then, it shows how they institutionalise strict surveillance, institutional denigration of the poor and professional scepticism. In general, the conclusions underpin one hypothesis that leads the analysis: eventually, these targeted education policies "pedagogise" poverty alleviation in that they aim to "instil flexible identities" into the poor rather than open channels for social inclusion.

\section{RESEARCH ARTICLE}

For decades, governments and international agencies have broadly assumed that education can teach the poor to cope with adversity on their own (World Bank, 2000). In Latin America they have been the driving forces behind sets of guidelines and good practice that concentrate pedagogic innovation and conditional cash transfers on the lowest performing schools and the poorest families. The schools are asked to develop new strategies, and the families to take responsibility for children's school attendance and vaccination. Currently, international organisations are drawing attention to persistent huge inequalities. Yet, policymakers are recommended to tackle them precisely by matching targeted schemes with general education and health policies (World Bank, 2006).

This article sets the context of these educational programmes (first section) and analyses their discourse on poverty (second section). Finally, it shows how they institutionalise strict surveillance, institutional denigration of the poor and professional scepticism in Argentina (third section) and Chile (fourth section). In general, one leading hypothesis states that these targeted education policies eventually "pedagogise" poverty alleviation in that they aim to "instil flexible identities" into the poor (Bernstein and Solomon, 1999) rather than 
open channels for social inclusion.

\section{Education policies for the poor}

International organisations recommend two kinds of initiative strategically geared to curbing poverty and the associated signs of social exclusion and vulnerability. On the one hand, over the last few decades most accredited programmes have required mothers to send their children to school every day, with the expectation that education and welfare expansion will counteract poverty in many middle- to low-development countries such as Argentina, Bangladesh, Brazil, Chile, Colombia, Guatemala, Honduras, Indonesia, Malawi, Mexico or Nicaragua (Aguerrondo, 2007; Reimers et al., 2007). It is assumed that education plays a direct role, in the form of human capital, and an indirect role via improved skills for political democracies (World Bank, 2000, 2004 and 2006; InterAmerican Development Bank, 1998).

On the other hand, many governments have also implemented inclusive programmes targeted on the most disadvantaged schools. Brazil's Fundescola Programme and Mexico's High Quality Schools Programme, Chile's 900 Schools Programme and High School for All Programme and Argentina's Social Education Plan and Integral Programme for Educational Equality are notable examples. These initiatives normally rely on scholarship schemes, pedagogic innovation and community involvement to regenerate vulnerable schools.

In Argentina and Chile, families receive scholarships if they guarantee that their children will fulfil their school responsibilities, and schools receive more professional and material support if they deploy constructivist pedagogic techniques, implement teamwork and 
quality management and involve local families in school life so that the most disadvantaged educational communities acquire the basic skills necessary for local progress (Ministry of Education, Chile, 2002 and 2004; Ministry of Education, Argentina, 2004a and b).

In Argentina, the Menem administrations (1989-1999) devised the Social Education Plan and, at the same time, reformed the curriculum and decentralised responsibility for education. The successor government led by the Alliance (1999-2001) made only slight changes, but since 2003 the (Néstor and Cristina Fernández de) Kirchner administrations have repeatedly claimed that former targeted policies were reformed to overcome the terrible consequences of the $2001 \mathrm{crash}$. In the medium term, although the core scheme of targeted scholarships has been maintained, the Integral Programme for Educational Equality aims to broaden the range of intervention and take a more community- driven direction. The official line is that better management, greater respect for the teaching profession and local participation are conducive to progress for the poor and for the whole system.

Since 1990, the Chilean administrations have been applying targeting in primary, rural, intercultural and secondary education. They want to take affirmative action for vulnerable schools by stimulating them with innovative teamwork and curriculum development. After 2000, this action was transferred from primary (900 Schools Programme) to secondary education (High School for All Programme).

These two countries provide a small, but significant sample allowing comparison of two education systems with similar political histories. Overall, however, they are salient because, 
despite ideological nuances, their governments have actively experimented with these methods, which open a new phase in inclusive education according to some educationalists (Aguerrondo, 2007). This article draws on fieldwork conducted in each of these countries in order to compile a corpus of official documents and interviews and carry out a critical discourse analysis following Norman Fairclough's (2003) approach.

In Argentina, in 2004 we interviewed the Federal political heads of the first experiments implemented in the nineties and also the heads and staff of the programmes adopted by the Néstor Kirchner administration, namely the Programa Integral de Igualdad Educativa (Integral Programme for Educational Equality), the Plan de Inclusión Educativa (Educational Inclusion Plan) and the Plan Nacional de Becas Estudiantiles (Scholarships Plan). In 2006 this sample was expanded by interviewing the staff of these programmes in Buenos Aires Province. The final corpus consisted of twenty documents, including interviews and written policy presentations. In Chile, in 2003 we interviewed the staff of the Programa 900 Escuelas (900 Schools Programme) and of the Programa Liceo para Todos (High School for All Programme), that is to say the managers of these initiatives under the Ricardo Lagos administration. In 2006 the sample was expanded by adding interviews with staff in the municipality of San Fernando (O'Higgins region). In this case, the final corpus consisted of fifteen documents, once again including interviews and written policy presentations.

\section{Evaluating the poor}

In order to spell out the discursive implications of the above-mentioned policies, we apply critical discourse analysis to political-cultural struggles and competing world views in educational policy-making (Ball, 1994; Bernstein, 1996; Popkewitz, 1991). This method 
scrutinises the ideas which subjects use to describe reality and advance their interests. Critical discourse analysis is suited to exploring the emergent dominant discourses, the way they are circulated through many channels and their reception, both negotiated and contested, in various fields. Pedagogic discourse is certainly one of them.

The key point is that people express their beliefs and desires with messages and their particular identities with discursive styles. Genres (e.g. poetry, novels, essays, news reports, research articles, etc.), which are defined as the discursive aspect of ways of acting, simultaneously transmit and shape messages that qualify a coherent discourse, modulate its connotations, combine different discourses or create new ones (Fairclough, 2003). In a given society, now and then powerful individuals recall discourse variation, select a singular discourse and harness its resonance. Actually, the core of modern politics intermingles with these processes insofar as States define and enforce collectively binding decisions in the name of the general will (Jessop, 2007: 9-11).

The structure of the pedagogic discourse consists of rules enacted in the corresponding fields of activity. Basically, educators recall rules of distribution to delimit school knowledge, rules of recontextualisation to transform it into the school curriculum and rules of evaluation to assess students' learning against these criteria.

The prevailing rules of distribution allow networks of policy-makers, scholars, lobbies, political parties, unions and social movements to fashion school knowledge by distinguishing between fact and fiction, desirable and undesirable practices, the feasible and the unrealistic and so on (Popkewitz, 1991). The rules of recontextualisation put this selection into a format 
that educators and students can incorporate easily into their daily routines. In the end, students, parents and teachers appraise educational interaction with reference to rules of evaluation that work to the advantage of the more powerful and prestigious social groups by promoting certain cultural traits and disciplines and by using abstract intellectual and learning styles unconnected to local contexts (Bernstein, 1996). The cognitive outcome is likely to be more or less elaborate, depending on the (dis)continuities between family and school pedagogies, but some pedagogic innovations may partly bridge this gap between family and school education (Lingard and Mills, 2007).

Recently, several authors have argued that vocational programmes, medical institutions and social insertion programmes are "pedagogised", in that they use the pedagogic discourse to transmit flexible labour identities to the young or the unemployed, teach patients to improve on their own endeavours and induce the beneficiaries of social assistance to work for their own social insertion (Bernstein and Solomon, 1999; Edwards, 2002; Singh, 2002). In our view, poverty alleviation is "pedagogised" in Argentina and Chile too, since the abovementioned programmes recall three rules of evaluation. To a large extent, in both these countries the mainstream international guidelines on inclusive education have been negotiated and eventually recontextualised by partial opposition and dialectic combination of "technical" and "community" understandings. Besides this, poverty alleviation appears to be driven by evaluation in that the resulting approaches entail surveillance (first rule of evaluation) and a subordinate image of the poor (second rule) and, paradoxically, wide scepticism (third rule) among first-line educators and social workers.

\section{Discourse analysis in Argentina}


After the hard 1976-83 dictatorship a huge, broad-based National Pedagogic Conference debated how to overhaul the whole Argentine education system. However, a further intense crisis delayed any reform until the early nineties, when the Menem administration combined the traditional people-centred agenda of "justicialismo" with neoliberal social and economic policies. A team of educationalists ran the Ministry of Education with the intention of changing the curriculum (on constructivist grounds), accompanied by complete decentralisation to the provincias and introduction of the Social Education Plan in favour of the most vulnerable schools. At the same time, social protection was extended and unemployment benefit was tied to community work.

This approach remained unchanged after Menem's incumbency, but became a symbol of wrong solutions for the governments which tackled the 2001 downturn. In early 2002 cash transfers were extended without any connection to employment, and when the Kirchner administration took office in 2003 it launched a new Integral Programme for Educational Equality as a significant reform of the earlier urban education policies.

Our interviewees continuously referred to these political conflicts, which triggered a lively debate on education policy in 2004 and 2005 (see, for example, Tedesco, 2005). Those who had worked in the Menem administration argued that the Social Education Plan had introduced key innovations (e.g. child-centred pedagogy, cross-curricular subjects and later school-leaving age) that eventually improved learning and countered poverty. Their opponents countered this point with a general appeal to the nation, the school system and individual schools as communities engaged in education. 
However, they all agreed that innovation should start with the poorest and that educational change should then gradually be extended to the whole system. In fact, this was the main task of the earlier plan and of the new Integral Programme for Educational Equality. In our view, this consensus reflects a process of discourse selection out of the variety of proposals discussed at the Conference and then opposed to an extreme extent in the 1990s and early 2000s.

Social justice policies entail the right to education. We aim to develop the Integral Programme for Educational Equality that will start with children in primary school who live in vulnerable social conditions. In later years more schools will be included in the programme (Ministry of Education, 2004).

In this analysis, in each country the interviews and written documents were coded to single out the "context" (e.g., poverty, social structure), the "process" (e.g. pedagogy, management, participation) and the "outcome" (e.g. academic performance, graduation rates, graduate employment) of education, that is the educational "function of production". Interestingly, in spite of the general current confrontation in Argentina most respondents overlooked contextual constraints and relied on change induced by school processes. Those who had been in charge of education policies in the nineties highlighted the personal dimension of poverty and were much more confident about the potential of pedagogical and psychological intervention to deal with the problem. And those who were closer to Kirchner expected to counteract structural inequality with popular participation.

Since the dominant message brought the behaviour of the poor and the routine of their 
children's schools to the forefront of public discussion, we conclude that these policies favoured school-based surveillance of the disadvantaged. In essence, institutional attention focused mostly on the everyday practice of a clearly identified bottom tier of schools, overlooking divides due to uneven expenditure (e.g. between public and private schools or between poorer and richer provinces), ineffective regulation of selective school admissions and patchy implementation of reforms in some provinces. This is a significant consensus given the abundant findings pointing to a fragmented school system in the country (Duschatzky and Redondo, 2000; CIPPEC, 2003; Tiramonti, 2007).

Interestingly, official documents solved this contradiction by means of an "additive list". This rhetorical resource neutralises antitheses by juxtaposing ideas with many coordinated statements (Fairclough, 2003). In our corpus, the Guidelines for the Integral Programme for Educational Equality reflected the contradiction between the "technical" and the "community" perspectives by means of a subtle distinction between principles, purposes and action. Consequently, the more general principles referred to structural conditions, whereas (more specific) action was circumscribed to consultants, trainers and collaborative teachers dealing with selected schools in a more empathetic way.

\section{General principles:}

- $\quad$ Starting from both equal opportunities and equal capabilities (...)

- Providing necessary and material resources so that all children are educable (...) Action:

- Ministerial consultants help schools to plan their own pedagogic innovation (...)

- In-service training is scheduled through seminars and meetings (...) 
- Schools' collaborative action with the community will be fostered (...)

- The Ministry will deliver a library, several computers, uniforms and stationery to targeted schools $(\ldots)$

- The Ministry will contribute to improving facilities (... ) (Ministry of Education, Argentina, 2004a)

Many interviews with the staff of provincial and local educational services and with a specialist in child labour brought out another solution to this contradiction. In the view of the respondents, the main practical objective was to change the culture of poverty, that is to say, to make children and families aware of the importance of education. The following excerpts are examples of the comments made on the retention scholarships introduced after 2004, a policy of keeping school playgrounds open on Saturdays, the difficulty of curbing child labour and the connection between cash transfers and infant education. The interviewees identified the poor as the target of these small but partly reliable schemes, and were mostly concerned with judging the rights or wrongs of their attitudinal change.

In the Province of Buenos Aires a major remedial programme offers scholarships conditional on school attendance. Children who have already dropped out of school are taught in transition classrooms that are expected to become a "bridge" between their experience and mainstream school behaviour (Interview with Education Department staff, Province of Buenos Aires, 2006).

The National Scholarships Programme also pays the wages of teachers who open school playgrounds at weekends. Actually, teenagers are very cruel, but they can learn to be cooperative in football competitions organised in their own school and monitored by educators on Saturdays and Sundays (Staff of the National Scholarships Programme, Province of Buenos Aires, 2006). 
A multinational has decided to offer scholarships to teenagers, provided they quit their job. Since families could well accept the money but overlook their commitment to full-time schooling, social educators will try to collaborate with them to make parents realise that their children must leave working for school life (Interview with Child Labour Department staff, Ministry of Work, Buenos Aires City, 2006).

Many mothers do not send their children to school. However, we should not rely on sanctions but on persuasion to change their mind. A social benefit does not solve poverty on its own; it is a single piece in the more complex, total, educative intervention necessary (Interview with Early Care and Education Programme staff, Municipality of Rosario, 2006).

\begin{abstract}
Although they generally declared that education was the resource which came last in critical times, none of the principals interviewed pointed either to tangible signs of upward education-driven social mobility or to strong synergies between education and social programmes. In their view, schools were a surviving public space in a divided society, where technical or community targeting provided a remedy that was unlikely to overcome the deep constraints of poverty, child labour, gangs and drug addiction.
\end{abstract}

Most students drop out in their early secondary education. However, schools must disguise this fact, and actually do so, in order to maintain their enrolment and their funding (Interview with School Principal, Province of Buenos Aires, 2004).

Our utopia is to introduce those kids who come to play football at the weekend into the ordinary proschool culture that you can find in, say, a maths or language lesson in the 8th or 9th year. Social benefits start with support for resocialisation, which is basically a commitment to "walk towards". 
These special programmes would eventually work, but they do not because of students' poor maternal language and peer-groups (Interview with School Principal, Province of Salta, 2004).

Principal: In our view, children are able to overcome poverty if they are treated as subjects and teachers use innovative methods.

Question: What about the outcomes?

Principal: They are not admirable, certainly. They are not very satisfactory. Certainly, some problems are alleviated, but our academic performance is not the best. It seems contradictory, because we do actually draw on innovation, but maybe the initial opportunities are really worse here than in many private schools. However, we focus on socialisation, cooperation, friendship, solidarity and fighting against segregation; thus, our goals are not only technical and cognitive, but also personal and attitudinal (Interview with School Principal, Buenos Aires City, 2004).

\section{Discourse analysis in Chile}

Despite stronger political stability, Chileans often express deep anxiety about the contribution made by education to poverty reduction and social justice. The most influential educational reforms were implemented by the authoritarian government of the Junta Militar led by Augusto Pinochet (1973-1990). In 1985 quasi-markets were established by decree and the Constitutional Education Act regulated the legal status of private, private dependent and municipal schools in the last piece of law approved by a dictatorial government. Subsequent democratic reforms launched an urban education initiative promoted by international aid during the political transition (finally called the "900 Schools Programme") and changed the curriculum up to the mid-nineties. Afterwards, democratic governments also pushed for the extension of full-day schools, implemented targeted education at secondary level (the High School for All Programme) and decided to experiment with positive discrimination in the form of vouchers (schools are given extra 
money per student with special educational needs) in order to alleviate segregation. Nevertheless, concern about unsatisfactory outcomes is pervasive and strong (Brunner and Elacqua, 2003; Raczynski, 2007).

Unlike Argentina, in Chile the hegemonic discourse has not been debated for twenty years, but a few oppositional voices blame it for underlying processes of selection. Most institutional designs are often presented as a double reaction against Salvador Allende's socialist policies before the coup in 1973 and against Augusto Pinochet's ultra-liberal reforms in the eighties. Consequently, a socially sensitive education reform is keeping a symbolic distance from educationalists engaged in social movements in the seventies and also from top-down elitist quasi-markets. This has been the motto of incumbent governments since 1990, all of them led by a coalition including the traditional deeply rooted mass parties - the Christian Democrat, the Socialist and the Radical parties - and opposed by the Alliance of supporters of the reforms implemented in the 1980s.

In the final analysis, Chilean policy-makers, educationalists and teachers share a general, similar confidence in pedagogic innovation to neutralise the deep societal divides created by past dramatic events but consolidated in the more peaceful and affluent later decades. For them, reasonable and well-grounded recommendations guide effective education policies consisting of child-centred pedagogies, teamwork and psycho-social intervention. This was the prevailing view in our sample, but not the only one. 
The High School for All Programme works with schools where the worst educational and social disadvantages are concentrated. The school community makes its own decisions to implement new strategies, addressing pedagogic and psycho-social issues, in order to improve its retention rate.

The pedagogic area promotes remedial courses and innovation. The psycho-social area is concerned with adequate inter-personal relationships, so that the school climate favours actual learning (Ministry of Education, 2004 Support Programmes).

Never again teach students sitting in rows. They must sit in circles, seeing each others' faces (...) That is why one of the measures to be implemented is to reduce the number of pupils per classroom (Interview with primary school principal, Region VI of El Libertador, 2003).

There are various approaches. One consists of improving and updating teachers in their discipline maths, art, whatever it is.. Another, which is the approach we adopt, consists of delivering the courses (material) to permit teachers to update and learn effectively on their own. Because maybe the programmes will change again within five or ten years; the knowledge is being produced so quickly ... This method creates conventional learning spaces, where the interaction is direct and close (Interview with Ministry of Education staff, Santiago, 2003).

Once again, our analysis proceeded by distinguishing "context", "process" and "outcomes" as categories framed by the internationally official educational function of production. Unlike the Argentineans, the Chilean interviewees hardly attacked the "technical" approach to targeted inclusive education. Only the coordination team of one programme (who had resigned immediately before the interview) and some policy briefs published by the unions or left-wing NGOs included some criticism of these tenets, although seldom total opposition. Some written documents also suggested that their "technical" approach implied an evolved version of the "people education" that social movements had promoted in the 
seventies and eighties (Castillo, 2003).

The prevailing opinion shared interest in surveillance with the Argentineans, expressed by the focus of processes regardless of context, but here this implication was also emphasised by many clearer statements of fact. This is a rhetorical instrument of hegemony in that it disguises advice as factual, unchallengeable evidence (Fairclough, 2003). In Chile some evaluation reports argued that effective programmes must go straight to the home of vulnerable youngsters (Castillo, 2003). Many interviews gave quotes of this kind in order to underpin an increasing focus on management:

We worked with community management teams; we gave them tools, strategies and materials for them to disseminate the same methodology in their schools. This made it possible to disseminate, to achieve much more qualitative and quantitative progress and to change people's perception of management issues (Interview with Ministry of Education adviser, Santiago, 2003).

The P900 [900 Schools Programme] started in language and maths because these subjects are the object of the SIMCE [quality measuring system] tests. However, after that, they become aware that they have to contemplate management issues, that this is a key issue (...). Teachers, community representatives and, on occasions, children participate in the school-management teams (...). The team takes decisions on curricular issues and more cross-cutting objectives (Interview with Ministry of Education staff, Santiago, 2003).

In 2001 a research report about early school drop-out concluded that school factors rather than poverty were the main cause, since frustrating academic experience eventually pushed some students out. Thus, our strategy consists of targeting at-risk rather than the 
poorest students and asking teachers to look for educational alternatives (Interview with Ministry of Education staff, Santiago, 2003).

Fairclough (2000) highlighted how "nominalisation" portrays a passive target group of British anti-exclusion programmes by simply splitting the many occurrences of the name (the "excluded") from the few references to any verb designating their actions. In Fairclough's words "nominalisation is a type of grammatical metaphor which represents processes as entities by transforming clauses (including verbs) into a type of noun" (Fairclough, 2003: 220). Our Chilean interviewees reproduced the same effect many times, since their accounts shared the image of beneficiaries who were helpless despite education and assistance. In their view, "socially deprived sectors" could not be involved due to lack of social capital; teenagers who had completed primary education were still so "absorbed by life itself" that they reproduced even worse problems than their parents. In addition, rural education had failed to teach the young not to migrate from their villages to the metropolitan suburbs of Santiago.

For instance, one school counsellor made an unintended critique of social capital theory to justify the disappointing impact of targeted intervention in Chilean primary schools. The method had raised some indicators in the early nineties (at the same time as expenditure had increased and poverty declined), but had yielded stagnant academic standards later. $\mathrm{He}$ blamed poor communities for lack of social capital, regardless of all the official emphasis on the potential of social networks and trust to overcome poverty. 
Therefore, our diagnosis focused more on detecting the deficits of the teachers than on corroborating the deficits of the students. And then we tackled the concerns and deficits of school principals and the deficits of maths and language teachers (Interview with Ministry of Education advisor, Santiago, 2003).

One school principal "nominalised" his students, i.e. referred to their essences instead of their actions, to account for the difficulties in secondary education despite the good education his school delivered.

And, why am I telling you this? Because our children have another quality: their effort, they are hard-working. The problem comes when life catches up with a lot of them, when they are in the seventh or eighth year, life absorbs them and they become ... well ... The kids have to assume similar or even worse problems than their parents ... it happens to kids living in extreme poverty (Interview with primary school principal, Region VI of El Libertador, 2003).

These stereotypes were eventually framed by wide scepticism about the anti-poverty effects of education. In our interviews this point of view contradicted the official line in many subtle and sometimes unacknowledged ways. "Intercultural bilingual education" appears to embed this message in two ways. On the one hand, it is contradictory to restrict social rights to specific attention to an ethnic minority, since interculturalism is commonly associated with a drive towards universalism. On the other, the contradiction may become poignant if minorities are simply not expected to achieve the average academic standards.

All the research shows, does it not, that for years the living conditions of families and children exert great influence. For this reason, if a school moves up from 200 points to 250 , even if the national average is 400 , for us this is a great leap forward, because the school has been able to overcome all 
these limitations and structural determinants generated by capitalism, by the authoritarian model of society in which we live, generated by racism, generated by lack of expectations (Interview with Ministry of Education staff, Santiago, 2003).

Finally, students may also be reduced to alleged essences by labelling their academic problems as individual and psychosocial. Certainly, material shortcomings, early drop-out from school and many other social sides may be linked to psychological malaises, but to take these as the basis for a national programme poses a severe risk of overstatement (although it may be helpful to concentrate action on workshops and individual counselling).

We call it "differentiated pedagogy" because it aims to generate different ways for young people to achieve common goals. (...) "Differentiated" implies drawing a distinction between different groups in order to think about different teaching strategies for students to initiate different paths to reach the goal. (...) Because sometimes students understand, but there are other interferences. It is purely a psychological problem, rooted in their ego, in their anxieties and strong family problems (Interview with Ministry of Education staff, Santiago, 2003).

\section{Monitoring individual behaviour in a world of inequality}

According to our sample in both countries, education policy drew on anti-poverty recommendations analogous to compensatory education (Bernstein, 1970) and workfare (Handler, 2003). Programme missions, academic and political voices, assessment reports and teachers assumed that vulnerable schools and low-performing students had to be closely monitored (although in different ways), that they were not resilient due to embedded cultural or psycho-social problems and that, high expectations notwithstanding, educational measures made a weak contribution to the fight against poverty. These ideas were presented as the end-point of the national debate in Argentina in the eighties and also 
as the coherent solution to the radical-authoritarian dilemma many Chileans saw in their recent history.

They were often expressed by hegemonic discourses featuring additive lists, nominalisation and apparent statements of fact (Fairclough, 2003). Therefore, targeted, inclusive education appears to be the discourse finally selected and legitimised by both the official and academic fields of recontextualisation (Bernstein, 1996). Mostly, the general concern with educational development and societal divides is incorporated into the pedagogic discourse by committing policies to improving management, innovating teaching methods and, sometimes, stimulating participation.

These findings also reveal a continuous evaluation of schools', students' and families' behaviour. In selected schools these social groups were exposed to many political, professional and scientific judgements about their endeavours, their involvement in education and their aspirations. Contemptuous images of the poor and widespread professional scepticism also explained persisting obstacles which nobody knew how to surmount.

Noticeably, these discourses were propagated in a context of inertial divides. This is a crucial observation here, since context is an undeniable dimension of critical discourse analysis (Fairclough, 2003) and inequality is an obviously salient contextual reference for anti-poverty policies. In a nutshell, these divides have been visible in the development of Education for All, in social segregation within the school system and in sharp societal imbalances in the whole of Latin America and the Southern Cone over the last two decades. 
These data are particularly shocking in thriving economies like Argentina in 1992-97 and 2003-08 or Chile over the whole period. Although both countries score above the Millennium Development Goals, not only educational quality but also the very development of Education for All is far from satisfactory.

In Argentina, performance gaps persisted, despite its higher product per capita in the nineties (Willms and Sommers, 2001). Furthermore, at that time attendance also sustained a constant gap between the highest and lowest income quintiles for teenagers (1.2) and young adults (2.55) and regional disparities exacerbated the divide at the end of primary and secondary education. Afterwards, the percentage of the 13- to- 19-year-old population who attended school declined from $83.2 \%$ in 2002 to $78.7 \%$ in 2004 (CEPAL, 2005) and school life expectancy (primary to secondary) diminished from 12.7 years in 1999-2002 to 11.9 years in 2004-05 (CEPAL, 2003: Tables 32 and 39; CEPAL, 2005: Table 29; CIPPEC, 2003).

In Chile, the quality measuring system (SIMCE) recorded increasing performance in the early nineties, but the later data give cause for concern (García Huidobro, 2006; Raczynski, 2006 and 2007). However, net primary education rates worsened between 1990 (87.7\%) and $2002(84.8 \%)$ and the rate of primary school-age children out of school resisted at $6 \%$ in spite of growth and welfare expansion between 1999 and 2005. In other words, the country suffered a reversal on one key Millennium Development Goal (CEPAL 2003: Tables 32 and 39; CEPAL 2005: Tables 29 and 48; UNESCO Institute for Statistics, 2007).

The segregation of social groups into heterogeneous school intakes hampers both 
educational quality and equity in OECD countries and Latin America (OECDUNESCO/UIS, 2003; Willms and Sommers, 2001: Graphs 2a and 2b; Duru-Bellat, 2005: Table 8). Unfortunately, this barrier is still very high in Argentina and Chile, where there are no students from the lower socio-economic groups in private fee-paying schools and only a few in private dependent schools. Even worse, some vulnerable students still attend schools with two or more shifts a day, whereas the more integrated and prosperous families have all-day schools with more teaching hours (Narodowski and Nores, 2002; DESUC, 2001; Ministry of Education, Chile, 2004b; IIPE, 2004; Tiramonti, 2007).

Finally, three important features of the Latin American class structure shed new light on this social reality, namely huge levels of economic inequality, slow poverty reduction and a constant - or increasing - percentage of informal proletariat despite economic recovery (Portes and Hoffman, 2002; Torche, 2005: p. 443; CEPAL, 2005: Table I.4). Even though many of these inclusive educational programmes have made a difference compared with the hard times of the "lost decade" in the eighties, unfortunately they keep monitoring the weakest groups of extremely fragmented societies.

\section{Conclusions}

On the basis of official and academic publications and interviews, we analyse official discourses that link education and poverty alleviation in Argentina and Chile. After initial contention, in both these countries new official approaches to education and social policies are aiming to activate vulnerable students and families, along with low-performing schools, basically by reforming certain managerial and pedagogic practice. 
Discourse analysis helps to capture the interplay between stakeholders who use social rules in fields of social activity. In both these countries, official texts and oral statements highlight the individual behaviour of the poor and the particular management of "failing" schools. Although an allegedly creative and autonomous response is taken for granted, a set of rhetorical strategies (e.g. apparent statements of fact, additive lists and nominalisation) portray the beneficiaries as a subordinate, passive and weak group.

If discourse analysis is able to find this prevailing message, it is plausible to conclude that poverty alleviation is eventually "pedagogised" (Bernstein and Solomon, 1999). In point of fact, this conclusion coincides with many more relevant contributions by sociology to educational sciences. Although immediate experience and pedagogic best wishes tend to rely on step-by-step change, starting with everyday small innovations, there are powerful reasons to expect stronger inertia. In fact, pedagogic discourses convey power relations between the privileged and the weaker social classes in a number of social domains such as education, labour policies, public budget and so on. As a consequence, it is much more sensible to expect small advancement, unless significant changes occur in the leverage of these relations (e.g. until progressive taxation or universal social policies are implemented in these countries).

We also call for a deep debate on educational justice that should take account of broader issues than compensatory education in the Southern Cone. So far, these governments and their critics have already made a valuable contribution to the global educational agenda, since they have actively underpinned the conception of basic education beyond the minimum thresholds set by the Millennium Development Goals. They have invented a new, 
more sophisticated form of urban education, with a very rich array of nuances and implications. Nonetheless, today they could launch far more promising political projects if they were to take account of alternative, more encompassing means of promoting poverty reduction via educational sites. In both countries, current debates on educational reform offer a new opportunity to put these issues on the national agenda.

\section{References}

Aguerrondo, I. 2007. Inclusión-Exclusión. In International Workshop on Inclusive Education: Latin America, Southern and Andean Region. Buenos Aires: International Bureau of Education/ UNESCO.

Ball, S. 1994. Education Reform. A critical and post-structural approach. Milton Keynes: Open University Press.

Bernstein, B. 1970. A critique of the concept of compensatory education. Hardmondsworth: Penguin Books.

- 1996. Pedagogy, Symbolic Control and Identity. Theory, Research, Critique. London: Taylor \& Francis.

Bernstein, B. and J. Solomon,. 1999. 'Pedagogy, Identity, and the Construction of a Theory of Symbolic Control': Basil Bernstein questioned by Joseph Solomon. British Journal of Sociology of Education 20, no. 2:265-279.

Brunner, J.J. and G. Elacqua. 2003. Informe Capital Humano en Chile. Santiago de Chile: Universidad Adolfo Ibáñez.

Castillo, D. 2003. Desertores de la Educación Básica. Revista Latinoamericana de Innovaciones Educativas XIV, no. 37: 69-90 (Programa Interdisciplinario de Investigaciones Educativas http://www.piie.cl, accessed January 2005).

Castro, C. de M. et al. 2000. Reforming Primary and Secondary Education in Latin America and the Caribbean. An IDB Strategy. Washington: Publications, Education Unit. Inter-American Development Bank.

Centro de Implementación de Políticas para la Equidad y el Crecimiento CIPPEC. 2003. Proyecto 'Las Provincias Educativas',. Documentos de Trabajo 1-3. http://www.cippec.org, (accessed July 2004).

Comisión Económica para América Latina y el Caribe CEPAL. 2002. Panorama social de América Latina. Santiago de Chile: CEPAL. http://www.eclac.es/publicacion> (accessed October 2003).

- 2003. Panorama Social de América Latina. Santiago de Chile: CEPAL http://www.eclac.es/publicacion> (accessed September 2004).

- 2005. Panorama Social de América Latina. Santiago de Chile: CEPAL http://www.eclac.org/publicacion (accessed March 2006).

DESUC. 2001. Estudio de evaluación Jornada Escolar Completa. Santiago de Chile: Ministerio de Educación- Pontificia Universidad Católica de Chile. http://www.mineduc.cl/biblio/ (accessed April 2006).

Duru-Bellat, M., N. Mons and B. Suchaut. 2004. Caractéristiques des systèmes éducatifs et compétences des jeunes de 15 ans. L'éclairage des comparaisons entre pays. Cahiers de l'IREDU 66: 1- 164. http://www.u-bourgogne.fr/IREDU (accessed February 2005). 
Duschatzky, S. and P. Redondo. 2000. Las marcas del plan social educativo o los indicios de ruptura en las políticas públicas. In Tutelados y asistidos: programas sociales, políticas públicas y subjetividad, edited by S. Duschatzky. Buenos Aires: Paidos.

Education Ministry- Argentina Government (EM Argentina). 2004 a. Documento Base. Programa Integral para la Igualdad Educativa. Buenos Aires: MEC. http://www.me.gov.ar (accessed March 2006).

- 2004 b. El entorno educativo. La escuela y su comunidad. Buenos Aires: MEC. http://www.me.gov.ar (accessed March 2006).

Education Ministry- Chile Government (EM Chile). 2002. Innovación en Equidad y en Diversidad. El Programa 900 Escuelas. Santiago de Chile: MINEDUC Report for UNESCO. http://innovemosp.unesco.cl, (accessed April 2004).

- 2003. Examen SIMCE $8^{\circ}$ Básico y $2^{\circ}$ Medio. Resultados Nacionales. Santiago de Chile: MINEDUC http://www.mineduc.cl (accessed Octobre 2004).

—. 2004 a. Programa Liceo para Todos. Santiago de Chile: http://www.mineduc.cl/media/lpt, (accessed June 2004).

- 2004 b. Modificaciones de la Ley de Jornada Escolar Completa. Santiago de Chile: Ministerio de Educación http://www.mineduc.cl (accessed April 2006).

Edwards, T. 2002. A Remarkable Sociological Imagination. British Journal of Sociology of Education 23 (4):527-535.

Fairclough, N. 2000. The Language of 'Social Exclusion'. In New Labour, New Language? London and New York: Routledge.

- 2003. Analysing Discourse: Textual Analysis for Social Research. London: Routledge.

García Huidobro, J. E. 2006. La reforma educacional chilena y la educación pública. In Globalización, educación y pobreza en América Latina, edited by X. e. Bonal. Barcelona: CIDOB.

Handler, J. F. 2003. Social citizenship and workfare in the US and Western Europe: from status to contract. Journal of European Social Policy 13, no 3: 229- 243.

Instituto Internacional de Planeamiento de la Educación (IIPE). 2004. La extensión de la jornada escolar. Informes Periodísticos para su Publicación 25: 1-7. http://www.iipe-buenosaires.org.ar (accessed May 2006).

Inter- American Development Bank. 1997. A Strategy for Poverty Reduction. Washington D.C.: IDB.

Jessop, B. 2007. State Power: A Strategic-Relational Approach. London: Polity.

Lingard, B. and M. Mills. 2007. Pedagogies making a difference: issues of social justice and inclusion. International Journal of Inclusive Education 11, no. 3: 233-244.

Narodowski, M. and M. Nores. 2002. Socio-economic Segregation with (without) Competitive Education Policies. A Comparative Analysis of Argentina and Chile. Comparative Education 38, no 4: 429-451.

OECD and UNESCO/UIS. 2003. Literacy Skills for the World of Tomorrow-Further Results from PISA 2000. Paris: OECD. http://www.oecd.org, (accessed April 2004).

Organisation for Economic Co-operation and Development OECD. 2001. In the Face of Poverty. Meeting with Global Challenge Through Partnership. Paris: OECD. http://www.oecd.org/dac/poverty (accesed May 2002).

- 2004. Education and Equity. Policy Brief (February): 1-6. http://www.oecd.org/publications/Pol_brief (accessed April 2006).

. 2005. Education at a Glance. Paris: OECD, http://www.oecd.org (accessed January 2006). Popkewitz, Th. 1991. A political sociology of educational reform: Power/knowledge in teaching, teacher education and research. New York: Teachers College Press.

Portes, A. and K. Hoffman. 2003. Las estructuras de clase en América Latina: composición y cambios durante la era neoliberal. Serie Políticas Sociales de CEPAL 68. http://www.eclac.org (accessed March 2005). 
Raczynski, D. 2006. Cambio educativo en contextos de pobreza. Límites y aprendizajes de un programa de acción afirmativa en Chile. In Globalización, educación y pobreza en América Latina, edited by X. Bonal. Barcelona: CIDOB.

Raczynski, D. and G. Muñoz- Stuardo. 2007. Chilean Educational Reform: the intricate balance betwen a macro and a micro policy. In International Handbook of Urban Education, edited by W. T. Pink and G.W. Noblit. Dordrecth (NL): Springer.

Reimers, F., C. Shano da Silva and E. Trevino. 2006. Where is the "education" in Conditional Cash Transfers in Education? UIS Working Papers 4.

Singh, Parlo. 2002. Pedagogising Knowledge: Bernstein's theory of the pedagogic device. British Journal of Sociology of Education 23, no. 4: 571-582.

Taylor, S. 2004. Researching Educational Policy and Change in 'New Tlimes': Using Critical Discourse Analysis. Journal of Education Policy 19, no. 4: 433-451.

Tedesco, J. C. 2005. ¿Cómo superar la desigualdad y la fragmentación del sistema educativo argentino? Buenos Aires: UNESCO- IIPE.

Tiramonti, G. 2007. The fragmented composition of the Argentinean educational system. In International Handbook of Urban Education, edited by W. T. Pink and G.W. Noblit. Dordrecth (NL): Springer.

Torche, F. 2005. Unequal But Fluid: Social Mobility in Chile in Comparative Perspective. American Sociological Review 70 (June): 422-450.

UNESCO Institute for Statistics. 2007. Education Public Reports. http://stats.uis.unesco.org/unesco (accessed July 2007).

United Nations Development Program UNDP. 2004. La democracia en América Latina. Santiago de Chile: UNDP. http://www.undp.org (accessed October 2004).

- 2005. Inequality and human development. In Human Development Report. New York: UNDP.

Willms, J.D. and M.A. Sommers. 2001. Resultados escolares en América Latina. Santiago de Chile (and New Brunswick): UNESCO http://www.unesco.org> (accessed April 2003) (and Canadian Research Institute for Social Policy).

World Bank. 1990. World Development Report. Poverty. Washington: The World Bank Group http://www.worldbank.org (accessed August 2005).

_. 2001. World Development Report. Attacking Poverty. Washington: The World Bank Group http://www.worldbank.org (accessed May 2002).

—. 2004 a. World Development Report. Making Services Work For Poor People. Washington: The World Bank Group http://www.worldbank.org (acceso Junio 2004).

- 2004 b. Inequalities in Latin America. Breaking with the Past? Washington: The World Bank Group http://www.worldbank.org (acc Jun 2004).

- 2006. World Development Report: Equity and Development. Washington D.C.: The World Bank Group. 